\title{
Clinical value of the measurement of Mycobacterium tuberculosis specific antibody in pulmonary tuberculosis
}

\author{
G H Bothamley, R Rudd, F Festenstein, J Ivanyi
}

\begin{abstract}
Background A serological test that could help to diagnose tuberculosis, especially smear negative disease, would contribute to patient management.

Methods Levels of antibody to distinct antigens of Mycobacterium tuberculosis were assessed for their value in the diagnosis and management of pulmonary tuberculosis. Serum was taken from $\mathbf{5 2}$ patients who were smear positive, from 27 patients who were smear negative but with evidence of active tuberculosis (sputum culture positive in 16, response to antituberculosis chemotherapy in 11), from 11 patients with old healed tuberculosis (pre-antibiotic era), and from 39 healthy subjects vaccinated with BCG.

Results In smear positive tuberculosis an enzyme linked immunosorbent assay using a single $38 \mathrm{kDa}$ antigen gave a diagnostic sensitivity of $80 \%$ with a $100 \%$ specificity. In smear negative pulmonary tuberculosis, however, combination of the $19 \mathrm{kDa}$ antigen, lipoarabinomannan (ML 34 epitope), and hsp 65 (TB 78 epitope) was needed to achieve a sensitivity of $64 \%$ with a specificity of $95 \%$. Recurrent and extensive radiographic disease with a poor prognosis was associated with high anti-38 kDa and low anti-14 $\mathrm{kDa}$ antibody levels in patients with active disease. Patients with less pulmonary cavitation had high anti$19 \mathrm{kDa}$ titres. Bacteriological relapse during treatment was indicated by a rise in anti-14 kDa (TB68 epitope) antibodies. Four patients with non-tuberculous mycobacterial infection showed no anti$38 \mathrm{kDa}$ antibody.

Conclusion Antigen or epitope specific serology may help in the diagnosis, assessment of prognosis, and monitoring of chemotherapy in patients with pulmonary tuberculosis.
\end{abstract}

Tuberculosis remains an important health problem in the United Kingdom. ${ }^{12}$ The decline in incidence has slowed ${ }^{3}$ and diagnosis has become more difficult because of atypical presentations and a lack of familiarity with the disease among doctors. ${ }^{4}$ The mortality from tuberculosis has remained constant for the past decade at about $10 \%^{1}$ (A Fenton-Lewis, personal communication). The diagnosis of tuberculosis is readily made when a sputum smear contains acid fast bacilli. Subsequent culture will usually identify those patients with tuberculosis and those infected with other mycobacterial species after a delay of three to nine weeks. Clinical features that identify patients with a risk of greater morbidity include increasing age, alcoholism, neutrophilia and lymphopenia, and delayed diagnosis. ${ }^{56}$ Severe or extensive disease is associated with a reduced tuberculin response. $^{7}$ Short course chemotherapy for tuberculosis still lasts for six months and poor compliance with treatment is a common problem. ${ }^{8-10}$ A serological test capable of diagnosing smear negative tuberculosis, and also cases in which sputum is difficult to obtain, would be very helpful.

The usefulness of determining antibodies in tuberculosis has been largely dismissed since Mitchison et $a l^{11}$ could not reproduce the results of one such assay. ${ }^{12-13}$ Serological tests using crude antigens derived from tubercle bacilli have been unsuccessful owing to the broad cross reactivity of mycobacterial antigens. ${ }^{14}$ This problem has been overcome by the development of monoclonal antibodies that recognise antigenic determinants or epitopes specific for the Mycobacterium tuberculosis complex. ${ }^{15}$ These monoclonal antibodies have been used to measure levels of antibody to specific epitopes ${ }^{16}$ and to purify antigens for use in diagnostic assays. ${ }^{17-19}$ This study examined the diagnostic value of $M$ tuberculosis specific antibody and its association with the extent of disease, prognosis, and compliance with chemotherapy to investigate whether serological tests might have a role in the management of patients with pulmonary tuberculosis.

\section{Methods}

PATIENTS

1 Serum was obtained from 56 patients with acid fast bacilli detected in their sputum before the start of treatment; in 52 patients $M$ tuberculosis was cultured from sputum, six strains being resistant to isoniazid. In four patients non-tuberculous mycobacteria were identified. Fourteen of the smear positive patients had had tuberculosis before but had been free from disease for at least two years before the present episode. Thirty one of the patients with a positive smear were followed during treatment and serum samples were obtained seven, 14, 
and 28 days and two, three, four, and six months after the start of treatment.

2 Serum samples were also obtained from 27 patients whose sputum smear and bronchial washings had shown no acid fast bacilli; in 16 $M$ tuberculosis was subsequently identified by culture and the other 11 were treated on the basis of radiographic appearance alone and showed a good symptomatic and radiological response to antituberculous chemotherapy after non-tuberculous antibiotic treatment had failed.

Eleven patients with smear positive and three with smear negative tuberculosis had received $B C G$ vaccination.

3 Eleven further patients had a documented history of smear positive tuberculosis before the introduction of chemotherapy and had recovered without antibiotic treatment; repeated sputum samples in this group were consistently culture negative for $M$ tuberculosis. 4 Control serum was obtained from 39 healthy individuals vaccinated with BCG.

Radiographs were obtained before the start of treatment in all patients in addition to a full blood count and erythrocyte sedimentation rate. The radiographic extent of disease was assessed by dividing each lung field into three zones and giving a score of 1 for infiltration or 2 for infiltration and cavitation. A clinical scoring system $^{6}$ designed to predict mortality from tuberculosis was evaluated and compared with serological criteria.

\section{MONOCLONAL ANTIBODIES}

We used five monoclonal antibodies of restricted species specificity, TB68 (14 kDa antigen), TB23 (19 kDa antigen), TB71 and TB72 (38 $\mathrm{kDa}$ antigen) and TB78 $65 \mathrm{kDa}$ antigen), and one (ML34) that binds to lipoarabinomannan, a glycolipid common to mycobacteria. ${ }^{15-17}$

SOLID PHASE ANTIBODY COMPETITION TEST

Wells of polyvinyl flexible microtitre plates (Dynatech, Billingshurst, West Sussex) were coated with $50 \mu \mathrm{l}$ of a soluble extract of $M$ tuberculosis $\mathrm{H} 37 \mathrm{Rv} 30 \mu \mathrm{g} / \mathrm{ml}$ overnight at $4^{\circ} \mathrm{C}$. Non-specific binding was prevented by incubation with $3 \%$ bovine serum albumin for one hour at $20^{\circ} \mathrm{C}$. Four dilutions of serum $(1: 5$, $1: 25,1: 125$, and 1:625) were prepared in $3 \%$ bovine serum albumin and $25 \mu$ lincubated in duplicate wells at $20^{\circ} \mathrm{C}$ for four hours. Without being washed, $25 \mu 1$ of ${ }^{125}$ I labelled monoclonal antibody, diluted to give $1000-2000 \mathrm{cpm}$ when incubated in wells without competing serum (the high control), was added to each well and incubated overnight at $4^{\circ} \mathrm{C}$. After repeated washing wells were counted in an LKB 1260 Multigamma counter. Antibody titres were calculated as the dilution of serum causing $50 \%$ inhibition of binding of the labelled antibody $\left(\mathrm{ID}_{50}\right)$ by comparison with the high control after non-specific binding to wells coated with phosphate buffered saline had been subtracted from all values. ${ }^{18}$ This method measures antibody with the same or overlapping specificity as the monoclonal antibody without reference to class; early IgM responses are detected as readily as later IgG ones.
ENZYME LINKED IMMUNOSORBENT ASSAY WITH PURIFIED ANTIGENS

The 14,19 , and $38 \mathrm{kDa}$ antigens were purified by affinity chromatography, with the monoclonal antibodies TB68, TB23, and TB71. ${ }^{19}$ The $65 \mathrm{kDa}$ antigen, a recombinant protein, and lipoarabinomannan were also used. Microtitre plates (Immulon M129, Dynatech) were coated with $50 \mu \mathrm{l}$ of $0.2 \mu \mathrm{g} / \mathrm{ml} 14$ or $19 \mathrm{kDa}$ antigens, $0.35 \mu \mathrm{g} / \mathrm{ml} 38 \mathrm{kDa}$ antigen, $1 \mu \mathrm{g} / \mathrm{ml} 65 \mathrm{kDa}$ antigen, $0 \cdot 1 \mu \mathrm{g} / \mathrm{ml}$ lipoarabinomannan or with phosphate buffered saline overnight at $4^{\circ} \mathrm{C}$. Non-specific binding was blocked with phosphate buffered saline containing $0.05 \%$ Tween 20 (Sigma Chemical Company, Poole, Dorset) and 1\% skimmed milk (Sainsbury PLC: PBSTM). Fifty microlitres of four dilutions of serum $(1: 5,1: 25,1: 125$, and $1: 625)$ in PBSTM were incubated for one hour at $37^{\circ} \mathrm{C}$ in duplicate wells and after repeated washing $50 \mu$ l of goat anti-human IgG peroxidase conjugate (Bio-Rad Laboratories) diluted 1:3000 were incubated for one hour at $37^{\circ} \mathrm{C}$. After washing, bound peroxidase activity was measured with $0 \cdot 1 \mu \mathrm{g} / \mathrm{ml}$ tetramethylbenzidine in $0.1 \mathrm{M}$ citrate buffer $\mathrm{pH} 5 \cdot 1$ containing $0.01 \%$ hydrogen peroxide $(v / v)$ for 10 minutes, the reaction being stopped by the addition of $0.5 \mathrm{M}$ sulphuric acid. Optical densities were measured at $450 \mathrm{~nm}$ and the antibody titre was calculated as that dilution of serum giving 30\% of the plateau of a standard hyperimmune serum $\left(\mathrm{ABT}_{30}\right)$.

\section{STATISTICAL ANALYSIS}

Comparisons between groups were made by using the Mann-Whitney $U$ test. Antibody titres and clinical measures were compared by means of the Spearman rank correlation test. Antibody titres within the same group were compared by using Student's $t$ test. Values of $p$ were corrected for the number of tests ( $n$ ) by using the formula $p_{\text {corr }}=1-(1-p)^{n}$. Positive antibody titres were defined as those greater than $\log$ mean $+2 \mathrm{SD}$ of control values and the frequency of positive titres was compared by the $\chi^{2}$ test. The sensitivity, specificity, and negative and positive predictive values were calculated by the method of Toman. ${ }^{20}$

\section{Results}

DIAGNOSTIC VALUE OF SEROLOGY

Patients with smear positive pulmonary tuberculosis had raised titres of antibody to all the antigens and epitopes tested, but the response in smear negative disease was more restricted (table 1). The frequencies of positive titres of antibody in smear positive and smear negative patients to the $19 \mathrm{kDa}$ antigen $(61 \%$ and $58 \%)$ and ML34 epitope (54\% and $32 \%$ ) did not differ (table $1 ; \chi^{2}=0.01$ and $2.6, p>0.1$ ). A combination of positive titres of antibody to these two antigenic determinants and to the TB78 epitope gave the best diagnostic sensitivity in patients with smear negative pulmonary tuberculosis (table 2). A positive antibody titre in patients with smear negative, culture positive pulmonary tuberculosis was obtained on average 36 (median 33, range 19- 
Table 1 Antibody titres in controls and patients with pulmonary tuberculosis

\begin{tabular}{|c|c|c|c|c|}
\hline \multirow[b]{2}{*}{ Antigen or epitope $\dagger$} & \multicolumn{4}{|c|}{ Antibody titres (median (range $Q 1-3$ ): \% positive $\ddagger$ ) } \\
\hline & $\begin{array}{l}\text { Controls } \\
(n=39)\end{array}$ & $\begin{array}{l}\text { Self healed } \\
(n=11)\end{array}$ & $\begin{array}{l}\text { Smear negative } \\
(n=27)\end{array}$ & $\begin{array}{l}\text { Smear positive } \\
(n=52)\end{array}$ \\
\hline $\begin{array}{l}14 \mathrm{kDa} \\
\text { TB68 }\end{array}$ & $\begin{array}{l}1(0-3) ; 5 \\
4(3-6) ; 0\end{array}$ & $\begin{array}{r}23(6-43) ; 36 \\
6(5-11) ; 11\end{array}$ & $\begin{array}{c}25(1-40)^{\star \star} ; 46 \\
6(3-12) ; 11\end{array}$ & $\begin{array}{l}78(12-241)^{\star \star} ; 72 \\
14(9-21)^{\star \star} ; 50\end{array}$ \\
\hline $\begin{array}{l}19 \mathrm{kDa} \\
\text { TB23 }\end{array}$ & $\begin{array}{l}0(0-4) ; 3 \\
6(3-9) ; 0\end{array}$ & $\begin{array}{l}11(0-49)^{\star} ; 55 \\
8(4-9) ; 0\end{array}$ & $\begin{array}{l}12(2-25)^{\star \star} ; 58 \\
5(3-12) ; 4\end{array}$ & $\begin{array}{l}41(4-106)^{\star \star} ; 61 \\
17(8-36)^{\star \star} ; 46\end{array}$ \\
\hline $\begin{array}{l}38 \mathrm{kDa} \\
\text { TB71 } \\
\text { TB72 }\end{array}$ & $\begin{array}{l}0(0-0) ; 0 \\
1(0-2) ; 0 \\
2(1-4) ; 3\end{array}$ & $\begin{array}{l}0(0-0) ; 9 \\
2(1-2) ; 0 \\
4(1-5) ; 0\end{array}$ & $\begin{array}{l}0(0-0) ; 15 \\
2(1-4)^{\star \star} ; 11 \\
5(2-8) ; 18\end{array}$ & $\begin{array}{c}60(12-287)^{\star \star} ; 83 \\
7(2-26)^{\star \star} ; 56 \\
24(8-67)^{\star \star} ; 73\end{array}$ \\
\hline $\begin{array}{l}65 \mathrm{kDa} \\
\mathrm{TB78}\end{array}$ & $\begin{array}{l}79(23-181) ; 0 \\
0(0-1) ; 0\end{array}$ & $\begin{array}{c}317(37-514) ; 18 \\
1(0-4) ; 18\end{array}$ & $\begin{array}{c}107(19-290) ; 0 \\
1(0-4) ; 14\end{array}$ & $\begin{array}{c}172(71-566)^{\star} ; 11 \\
3(1-5)^{\star \star} ; 48\end{array}$ \\
\hline $\begin{array}{l}\text { LAM } \\
\text { LAM (IgM) } \\
\text { ML34 }\end{array}$ & $\begin{array}{l}48(3-127) ; 0 \\
10(0-25) ; 0 \\
15(10-20) ; 3\end{array}$ & $\begin{array}{l}9(0-307) ; 0 \\
0(0-12) ; 0 \\
18(14-30) ; 11\end{array}$ & $\begin{array}{l}69(31-440) ; 19 \\
29(4-63)^{\star} ; 0 \\
18(12-46)^{\star} ; 32\end{array}$ & $\begin{array}{l}1013(165-3125)^{\star \star} ; 40 \\
34(7-108)^{\star \star} ; 11 \\
\left.41(25-126)^{\star \star} ; 54\right)\end{array}$ \\
\hline
\end{tabular}

Patients were compared with controls by the Mann-Whitney $U$ test: ${ }^{\star} \mathrm{p}<0.01 ;{ }^{\star \star} \mathrm{p}<0.001$.

†Antibodies to purified antigens were IgG unless indicated otherwise; antibodies to individual epitopes were not class specific.

$\ddagger$ Positive titres were defined as $>\log$ mean $+2 \mathrm{SD}$ of control values.

63) days before the results of culture were available.

Although the frequencies of positive titres of antibody to the $38 \mathrm{kDa}$ antigen and its TB72 epitope did not differ, the use of lipoarabinomannan as a diagnostic reagent gave poorer results than the ML34 competition test (table 1). More than half $(54 \%)$ the patients with smear negative tuberculosis had an IgM antibody titre greater than the titre of IgG antibody to lipoarabinomannan, compared with $20 \%$ of those with smear positive disease $\left(\chi^{2}=5 \cdot 5, p=0.04\right)$.

\section{EXTENT AND SEVERITY OF DISEASE \\ Survival}

Four deaths occurred in patients with smear positive pulmonary tuberculosis, tuberculosis being the main cause in three. Titres of antibody to the TB71 epitope ( $38 \mathrm{kDa}$ antigen) were greater $(t=3.04, \mathrm{p}=0.03)$ and of IgG antibody to the $14 \mathrm{kDa}$ antigen were lower $(t=-3.26, \mathrm{p}=0.03)$ in the four who died than in survivors (figure).

No patient was identified as being likely to die from tuberculosis on the basis of clinical criteria, ${ }^{6}$ though a more unfavourable score was associated with lower anti liparabinomannan IgM antibody $(\mathrm{r}=0.43, \mathrm{p}=0.002$, $\left.\mathrm{p}_{\text {corr }}=0.03\right)$. Alcoholism and increasing age were associated with death $\left(\chi^{2}=8 \cdot 75\right.$, p $<0.01$ and 0.002 respectively): 15 patients with smear positive tuberculosis were over 65 or had an alcohol problem and three of these died during treatment. Serological criteria (TB71 titre $>25$, or $<25$ with a titre of $<11$ for the $14 \mathrm{kDa}$ antigen), however, would have been significantly better than clinical criteria for predicting mortality $\left(\chi^{2}=5 \cdot 6, p=0.02\right)$.

\section{Radiographic extent of disease}

Despite the crude scoring of the extent of radiographic disease there were correlations with anti-38 $\mathrm{kDa}$ antibody levels in smear positive tuberculosis $(r=0.39, p=0.005$, $\mathrm{p}_{\text {corr }}=0.049$ ) and with anti-19 kDa and anti liporabinomannan antibody titres in smear negative disease (for both $r=0.50, p=0.004$, $p_{\text {corr }}=0.039$ ). There was a negative correlation between cavitation and titres of antibody to the $19 \mathrm{kDa}$ antigen $(\mathrm{r}=-0.32, \mathrm{p}=0.017$, $\left.\mathrm{p}_{\text {corr }}=0.05\right)$ in those with smear positive tuberculosis.

Table 2 Serodiagnostic potential of Mycobacterium tuberculosis specific reagents

\begin{tabular}{|c|c|c|c|c|}
\hline \multirow[b]{2}{*}{ Test } & \multirow[b]{2}{*}{ Sensitivity (\%) } & \multirow[b]{2}{*}{ Specificity (\%) } & \multicolumn{2}{|c|}{ Predictive value ${ }^{\star}(\%)$} \\
\hline & & & + & - \\
\hline \multicolumn{5}{|c|}{ SMEAR POSITIVE PULMONARY TUBERCULOSIS } \\
\hline $\begin{array}{l}\text { Smear } \\
\text { Chest radiograph } \dagger \\
\text { Tuberculin } \ddagger \\
38 \mathrm{kDa} \text { antigen } \\
\text { TB72 epitope } \\
\text { Six epitopes }\end{array}$ & $\begin{array}{r}100 \\
41 \\
87 \\
80 \\
73 \\
90\end{array}$ & $\begin{array}{r}94 \\
99 \\
83 \\
100 \\
100 \\
92\end{array}$ & $\begin{array}{r}71 \\
93 \\
43 \\
100 \\
100 \\
62\end{array}$ & $\begin{array}{r}100 \\
94 \\
98 \\
97 \\
96 \\
99\end{array}$ \\
\hline \multicolumn{5}{|c|}{ SMEAR NEGATIVE PULMONARY TUBERCULOSIS } \\
\hline $\begin{array}{l}38 \mathrm{kDa} \text { antigen } \\
19 \mathrm{kDa} \text { antigen } \\
\mathrm{ML} 34 \text { epitope } \\
19 \mathrm{kDa} / \mathrm{ML} 34 / \mathrm{TB} 78\end{array}$ & $\begin{array}{l}15 \\
58 \\
32 \\
72\end{array}$ & $\begin{array}{r}100 \\
97 \\
100 \\
95\end{array}$ & $\begin{array}{r}100 \\
74 \\
100 \\
65\end{array}$ & $\begin{array}{l}90 \\
95 \\
92 \\
96\end{array}$ \\
\hline
\end{tabular}

$\star$ Predictive values have been calculated with Toman's formulae and data from the London Chest Hospital, where 1462

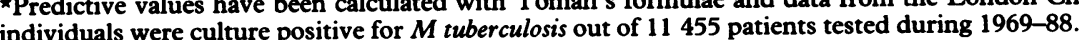

individuals were cultu

+Data from Toman.

tData from Chaparas et al. ${ }^{22}$ 

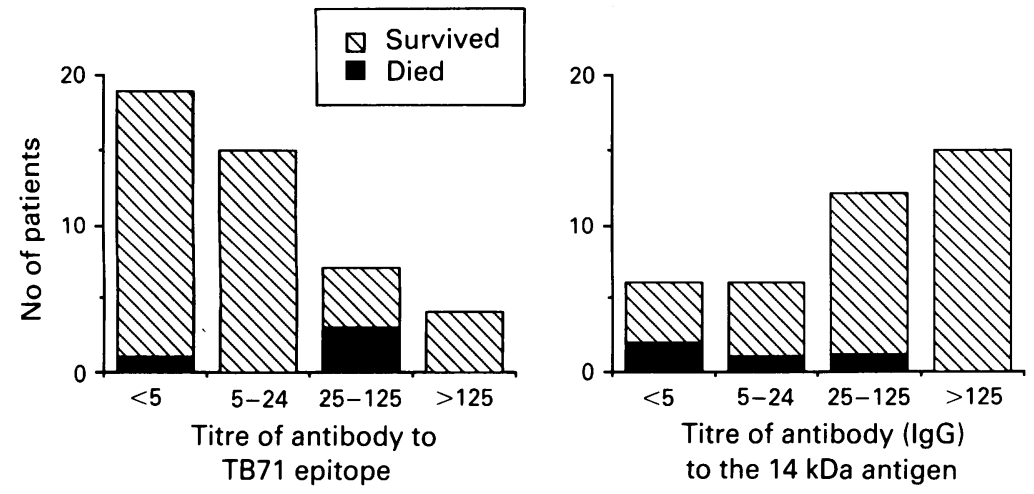

Relation between prognosis and titres of antibody to the TB71 epitope ( $38 \mathrm{kDa}$ antigen) and $14 \mathrm{kDa}$ protein antigen in patients with pulmonary tuberculosis. The titres of antibody to the TB71 epitope in the three patients whose tuberculosis was the main cause of death were 80,38 , and 0 and to the $14 \mathrm{kDa}$ antigen 63,11 , and 4 , compared with 27 and 4 respectively in the patient whose tuberculosis was merely a contributory factor in his death. titre for the TB68 epitope of the $14 \mathrm{kDa}$ antigen when they had become smear and culture negative, developed a positive titre of antibody to this epitope at the time that the culture positive sputum was obtained. Titres of antibody to the TB68 epitope were significantly greater in those who became culture positive than in those who did not during the same periods (table 3 ).

\section{Isoniazid resistance}

Isoniazid resistant strains of $M$ tuberculosis were grown from six patients, four of whom had recurrent tuberculosis. Titres of antibody to all the epitopes except for TB23 rose more slowly after treatment in these patients than in those from whom fully sensitive strains were cultured; significant differences were observed at two weeks (in all cases $t<-2.3, \mathrm{p}<0.04$ ). Titres of antibody to the TB72 epitope of the $38 \mathrm{kDa}$ protein at two weeks had fallen below pretreatment levels in all subjects with isoniazid resistant strains, a fall that occurred in only two patients with fully sensitive strains of $M$ tuberculosis $\left(\chi^{2}=4 \cdot 2, \mathrm{p}=0.04\right)$.

\section{Non-tuberculous mycobacteria}

Four patients were infected with atypical mycobacteria (one with $M$ aviumintracellulare, one with $M$ kansasii, and two with $M$ xenopi). One patient had a myeloma, but the other three had no evidence of immunosuppression and all were negative for HIV antigen and antibody. Two patients had weakly positive titres of antibody (2-3 SD above the log mean of control values-to the TB68 and TB78 epitopes respectively) at the start of treatment; none was positive for the TB71 and TB72 epitopes of the $38 \mathrm{kDa}$ antigen. No patient with atypical mycobacterial infection had a positive titre of antibody to any of the six epitopes two weeks after treatment had begun. patients with extensive pulmonary cavitation a positive smear persisted for up to four months but culture for $M$ tuberculosis was negative after two months; thus treatment was effective in all patients. In five patients a positive culture occurred during treatment after a period of negative cultures. There was no change in the antibiotic sensitivities of the cultured organism in any of these cases, suggesting that the patient had failed to continue treatment. All five patients, none of whom had a positive antibody

Table 3 Antibody titres in five patients considered to be non-compliant with treatment

\begin{tabular}{lcccccc}
\hline \multicolumn{7}{l}{ Relative antibody titre $\dagger$} \\
\cline { 2 - 7 } Patient No & TB23 & TB68 & TB71 & TB72 & TB78 & ML34 \\
\hline 10 & 1.19 & 1.62 & 1.50 & 0.75 & 0.84 & 0.81 \\
15 & 2.31 & 4.00 & 1.64 & 1.08 & 2.00 & 1.32 \\
34 & 2.09 & 13.30 & 8.14 & 2.41 & 2.50 & 2.82 \\
140 & 1.37 & 7.86 & 2.05 & 1.22 & 1.05 & 1.17 \\
163 & 1.50 & 1.67 & 2.45 & 2.95 & 0.50 & 1.79 \\
Other patients & 1.68 & $1.19_{\ddagger}^{\dagger}$ & 2.17 & 2.17 & 1.80 & 1.58 \\
\hline
\end{tabular}

* Mean relative antibody titres for the same periods in patients who did not become culture positive again during treatment.

tRatio between antibody titre when sputum was culture positive and the titre of the preceding sample, when sputum had been culture negative.

$¥$ Significantly less than the mean value for the five patients who had become culture positive during treatment (Student's $t$ test; $t=-3.25 ; \mathrm{p}=0.03$ ).

\section{Discussion}

This study has shown that $M$ tuberculosis restricted antigens can be used in the serological diagnosis of pulmonary tuberculosis. The serological test was as sensitive as but more specific than the use of tuberculin and could distinguish non-tuberculous mycobacterial disease from tuberculosis by the absence of anti-38 kDa antibody and no rise in levels of antibody to other $M$ tuberculosis specific epitopes and could detect patients with smear negative pulmonary tuberculosis before the results of sputum culture were available. In smear positive pulmonary tuberculosis, most patients had high titres of antibody to the $38 \mathrm{kDa}$ antigen, confirming the results of previous studies. ${ }^{18-1923-24}$ The $38 \mathrm{kDa}$ antigen is also contained in the antigen 5 preparation ${ }^{25-26}$ and is of value in serological diagnosis and screening for infectious tuberculosis. ${ }^{27-32}$ Serological tests in smear negative pulmonary tuberculosis have been disappointing. ${ }^{33-35}$ Our study is the first to show that a combination of antigens can achieve a sensitivity in smear negative pulmonary tuberculosis similar to that 
Table 4 Positive (+) and negative (-) associations between antibody specificity and clinical feature (associations with smear negative disease in bold type)

\begin{tabular}{|c|c|c|c|c|}
\hline \multirow[b]{2}{*}{ Clinical feature } & \multicolumn{4}{|l|}{ Antigen (epitope) } \\
\hline & $14 k D a(T B 68)$ & $19 k D a(T B 23)$ & $38 k D a(T B 71, T B 72)$ & $L A M(M L 34)$ \\
\hline Diagnosis & NS & + & + & + \\
\hline $\begin{array}{l}\text { Poor prognosis } \\
\text { Recurrent disease } \\
\text { Radiographically extensive disease } \\
\text { Cavitation }\end{array}$ & $\begin{array}{l}-\star \\
- \\
- \\
\text { NS }\end{array}$ & $\begin{array}{l}\text { NS } \\
- \\
+ \\
-\end{array}$ & $\begin{array}{l}+ \\
+ \\
+ \\
\text { NS }\end{array}$ & $\begin{array}{l}- \\
\text { NS } \\
+ \\
\text { NS }\end{array}$ \\
\hline $\begin{array}{l}\text { Non-compliance } \\
\text { Isoniazid resistance }\end{array}$ & $\begin{array}{l}+\dagger \\
\text { NS }\end{array}$ & $\begin{array}{l}\text { NS } \\
\text { NS }\end{array}$ & $\begin{array}{l}\text { NS } \\
-\ddagger\end{array}$ & $\begin{array}{l}\text { NS } \\
\text { NS }\end{array}$ \\
\hline
\end{tabular}

^A poor prognosis was associated with low titres of IgG antibody to the $14 \mathrm{kDa}$ antigen but not of antibody to the TB68 epitope.

+ Non-compliance was associated with a rise in the titre of antibody to the TB68 epitope.

$\ddagger$ Isoniazid resistance was associated with a fall in the titre of antibody to the TB72 epitope.

LAM-lipoarabinomannan; NS-no significant association.

of tuberculin testing but with greater specificity.

The use of monoclonal antibodies is an advance in the serological diagnosis of tuberculosis because they are readily prepared in a standard form, are free from the problems of cross reactivity, permit the measurement of both IgM and IgG antibodies in a single assay, and obviate the need to purify antigens from $M$ tuberculosis. Indeed, the TB72 competition assay fared as well as the use of purified $38 \mathrm{kDa}$ antigen in the serodiagnosis of smear positive tuberculosis. An ELISA modification of the competition assay ${ }^{36}$ can give a result in four hours with precoated plates and has been used successfully in the diagnosis of extrapulmonary tuberculosis. ${ }^{37}$ The cost of such an assay would be similar to that of an autoantibody screen. In smear negative pulmonary tuberculosis, however, purified $19 \mathrm{kDa}$ antigen will be needed until the epitope, which is not that defined by the MAB TB23, has been identified.

High titres of antibody to the $38 \mathrm{kDa}$ antigen were associated with more extensive and recurrent tuberculosis and increased mortality as well as being largely confined to those with smear positive disease whereas antibody to the $14 \mathrm{kDa}$ antigen was associated with a good prognosis and less radiographic infiltration in patients with self healed pulmonary tuberculosis (table 4). Antibody titres for these two antigens were more successful than a scoring system based on clinical criteria, ${ }^{6}$ or the factors of advanced age and alcoholism, in predicting who would be at greatest risk from tuberculosis. Inpatient treatment of tuberculosis is increasingly rare and the identification of patients at greatest risk would be valuable in deciding which patients require hospital admission.

The treatment of tuberculosis is necessarily prolonged and compliance is a problem. This study suggests that titres of antibody to the TB68 epitope of the $14 \mathrm{kDa}$ antigen could be used to monitor compliance by indicating those who had become culture positive again; such patients might then electively receive supervised chemotherapy. Isoniazid resistant strains of $M$ tuberculosis were associated with a failure of antibody titres to rise after two weeks' treatment; adding other drugs to the standard regimen of rifampicin, isoniazid, and pyrazin- amide could be considered in such patients Non-tuberculous mycobacterial infections were associated with an absence of anti-38 $\mathrm{kDa}$ antibody despite a positive sputum smear. $M$ kansasii and $M$ xenopi are the two most commonly isolated non-tuberculous mycobacterial species in the London area ${ }^{37}$ and are usually resistant to pyrazinamide and isoniazid. While bacteriological confirmation is awaited, this group of patients could also receive ethambutol or streptomycin, or both-drugs recommended for the treatment of non-tuberculous mycobacterial infections ${ }^{38-40}$-in addition to standard triple chemotherapy.

The measurement of titres of antibody to $M$ tuberculosis specific antigens may be of value in the diagnosis of both smear positive and smear negative pulmonary tuberculosis. Antibody titres may also help to determine which patients should be treated in hospital, which require supervised chemotherapy, and which might require the addition of other drugs to the standard regimen for the treatment of tuberculosis. This study has established which antigens or their epitopes might be of value in the management of patients with tuberculosis, together with cut off titres. Prospective evaluation of the role of serology, comparing patients whose antibody titres affected clinical management with patients where antibody levels were not known, together with a cost-benefit analysis, is essential before widespread use of these tests can be recommended.

We thank J van Embden (National Institute of Public Health and Hygiene, Bilthoven, The Netherlands) for the $65 \mathrm{kDa}$ antigen, produced with suppert from the UNDP/World Bank/ WHO-TDR special programme; Patrick Brennan (Fort Collins, University of Colorado, USA) for lipoarabinomannan; and $M$ Pearson and M Rubens for the use of chest radiographic data.

1 Horne NW. Problems of tuberculosis in decline. BMJ 1984;288: $1249-51$.

2 Cook GC. Tuberculosis-certainly not a disease of the past! QJ Med 1985;56:519-21.

3 Davies PDO. The slowing of the decline in tuberculosis notifications and HIV infection. Respir Med 1989;83: $321-2$.

4 McNichol M. Trends in the epidemiology of tuberculosisa physician's view. J Clin Pathol 1983;36:1087-90.

5 Humphries MJ, Byfield SP, Derbyshire JH, Davies PDO, Nunn AJ, Citron KM, et al. Deaths occurring in newly notified patients with pulmonary tuberculosis in England and Wales. Br J Dis Chest 1984;78:149-58.

6 Barnes PF, Leedom JM, Chan LS, Wong SF, Shah J, Vachon LA, et al. Predictors of short-term prognosis with pulmory tuberculosis. J Infect Dis 1988:158:366-71. 88:366-71.

7 Howard WL, Klopfenstein MD, Steinmenger WJ, Woodruff CE. The loss of tuberculin sensitivity in certain patients 
with active pulmonary tuberculosis. Chest 1970;57:530-4.

8 British Thoracic Society. A controlled trial of 6 months; chemotherapy in pulmonary tuberculosis. Final report: results during the 36 months after the end of chemotherapy and beyond. Br J Dis Chest 1984;78:330-6.

9 American Thoracic Society and the Centers for Disease Control. Treatment of tuberculosis and tuberculosis infection in adults and children. Am Rev Respir Dis 1986;134:355-63.

10 Committee on Treatment of the International Union against Tuberculosis and Lung Disease. Anti-tuberculosis regimens of chemotherapy. Bulletin of the International Union Against Tuberculosis and Lung Disease 1988;63: 60-4.

11 Mitchison DA, Aber VR, Ahmed FJ, Allen BW, Devi S Evaluation of a serological test for tuberculosis. $B M J$ 1977;i:1383-7.

12 Nicholls AC. A serodiagnostic test for tuberculosis. J Clin Pathol 1975;28:850-3.

13 Nicholls AC, Horsefield K. Serological diagnosis of tuberculosis; a report of 12 months' clinical experience. Thorax 1976;31:289-93.

14 Grange JM. The humoral immune response in tuberculosis: its nature, biological role and diagnostic usefulness. $A d v$ Tuberc Res 1984;21:1-78.

15 Coates ARM, Hewitt J, Allen B, Ivanyl, J, Mitchison DA. Antigenic diversity of Mycobacterium tuberculosis and Mycobacterium bovis detected by means of monoclonal antibodies. Lancet 1981;ii:167-9.

16 Ivanyl J, Morris JA, Keen M. Studies with monoclonal antibodies to mycobacteria. In: Macario AJL, Conway de Macario E, eds. Monoclonal antibodies against bacteria. Vol 1. New York: Academic Press, 1985:59-90.

17 Engers HD, Houba V, Bennedsen J, Buchanan TM Chaparas SD, Kadival G, et al. Results of a World Health
Organization sponsored workshop to characterise antigens recognised by mycobacteria-specific monoclonal antibodies. Infect Immun 1986;51:718-20.

18 Hewitt J, Coates ARM, Mitchison DA, Ivanyi J. The use of murine monoclonal antibodies in the serodiagnosis of tuberculosis. J Immunol Meth 1982;55:205-11.

19 Jackett PS, Bothamley GH, Batra HV, Mistry A, Young DB, Ivanyi J. Immunodominance and specificity of mycobacterial antigens and their epitopes in the serology of tuberculosis. J Clin Microbiol 1988;26:2313-8.

20 Toman K. Sensitivity, specificity and predictive value of diagnostic tests. Bulletin of the International Union Against Tuberculosis 1981;56:18-28.

21 Toman K. Casefinding. In: Tuberculosis, case-finding and chemotherapy: questions and answers. Geneva: World Health Organisation, 1979;3-65.

22 Chaparas SD, MacVandiviere H, Melson I, Koch G, Becker C. Tuberculin test: variability with the Mantoux procedure. Am Rev Respir Dis 1985;132:175-7.

23 Ivanyi J, Krambovitis E, Keen M. Evaluation of a monoclonal antibody (TB72) based serological test for tuberculosis. Clin Exp Immunol 1983;54:337-45.

24 Hoeppner V, Jackett PS, Swanson Beck J, Kardjito T, Grange JM, Ivanyi J. Appraisal of the monoclonal antibody-based competition test for the serology of tuberculosis in Indonesia. Serodiagnosis and Immunotherapy 1987;1:69-77.

25 Olds GR, Sanson AJ, Daniel TM. Characterisation of
Mycobacterium tuberculosis antigen 5 epitopes using a panel of 19 monoclonal antibodies. J Clin Microbiol 1987;25:471-5.

26 Wiker HG, Harboe $M$, Bennedsen J, Closs $O$. The antigens of Mycobacterium tuberculosis H37Rv studies by crossed immunoelectrophoresis. Scand J Immunol 1988;27: 223-39.

27 Benjamin RG, Daniel TM. Serodiagnosis of tuberculosis using the enzyme-linked immunosorbent assay (ELISA) of antibody to Mycobacterium tuberculosis antigen 5. Am Rev Respir Dis 1982;126:1013-6.

28 Balestrino EA, Daniel TM, de Latini MDS, Laini OA, Ma $\mathrm{Y}$, Scocozza JB. Serodiagnosis of pulmonary tuberculosis in Argentina by ELISA of IgG antibody to Mycobacterium tuberculosis antigen 5 and tuberculin purified protein derivative. Bull WHO 1984;62:755-61.

29 Daniel TM, Debanne SM, van der Kuyp F. Enzyme-linked immunosorbent assay using Mycobacterium tuberculosis antigen 5 and PPD for the serodiagnosis of tuberculosis. Chest 1985;88:388-92.

$30 \mathrm{Ma}$ Y, Wang Y-M, Daniel TM. Enzyme-linked immunosorbent assay (ELISA) using Mycobacterium tuberculosis antigen 5 for the diagnosis of pulmonary tuberculosis in China. Am Rev Respir Dis 1986;134:1273-5.

31 Alde SLM, Pinasco HM, Pelosi FR, Budani HF, PalmaBeltran $\mathrm{OH}$, Gonzalez-Montaner LJ. Evaluation of an enzyme-linked immunosorbent assay (ELISA) using IgG antibody to Mycobacterium tuberculosis antigen 5 in the diagnosis of active tuberculosis in children. Am Rev Respir Dis 1989;139:748-51.

32 Daniel TM, de Murillo GL, Sawyer JA, Griffin AM, Pinto $\mathrm{E}$, Debanne $S$, et al. Field evaluation of any enzyme-linked immunosorbent assay for the serodiagnosis of tuberculosis. Am Rev Respir Dis 1986;134:662-5.

33 Turner M, van Vooren J, de Bruyn J, Serruys E, Dierckx P, Yernault J. Humoral immune response in human tuberculosis: Immunoglobulins $G, A$ and $M$ directed against the purified P32 protein antigen of Mycobacterium bovis Bacillus Calmette-Guerin. J Clin Microbiol 1988;26: 1714-9.

34 Sada E, Ferguson LE, Daniel TM. An ELISA for the serodiagnosis of tuberculosis using a $30,000-\mathrm{Da}$ native antigen of Mycobacterium tuberculosis. J Infect Dis 1990;162:928-31.

35 Sada E, Brennan PJ, Herrera T, Torres M. Evaluation of lipoarabinomannan for the serological diagnosis of tuberculosis. J Clin Microbiol 1990;28:2587-90.

36 Wilkins EL, Bothamley G, Jackett P. A rapid, simple enzyme immunoassay for detection of antibody to individual epitopes in the serodiagnosis of tuberculosis Eur J Clin Microbiol Infect Dis 1991;10:559-63.

37 Wilkins EGL, Ivanyi J. Potential value of serology for the diagnosis of extrapulmonary tuberculosis. Lancet 1990;336:641-4.

38 Smith MJ, Citron KM. Clinical review of pulmonary disease caused by Mycobacterium xenopi. Thorax 1983;38:373-7.

39 Banks J, Hunter AM, Campbell IA, Jenkins PA, Smith AP Pulmonary infection with Mycobacterium kansasii in Wales 1970-9: a review of treatment and response. Thorax 1983;38:271-4.

40 Wolinsky E: Nontuberculous mycobacteria and associated diseases. Am Rev Respir Dis 1979;119:107-59. 